\title{
ARTE ALLUSIVA: A REPRESENTAÇÃO DE MEDEIA NA ARGONÁUTICA DE APOLÔNIO DE RODES E NAS METAMORFOSES DE OVÍDIO
}

\begin{abstract}
Fábio Gerônimo Mota Diniz*
RESUMO: O presente texto tem por objetivo analisar a notável influência da aparição da personagem Medeia no poema épico helenístico Argonáutica, de Apolônio de Rodes, especialmente no canto III, sobre a representação da mesma personagem no Livro VII das Metamorfoses de Ovídio. A análise se dará, sobretudo, sob a ótica da chamada arte allusiva, procedimento análogo à moderna intertextualidade, que incide sobre as relações de influência entre as obras clássicas. Partindo da relação existente entre os poetas helenísticos como influência para os escritores romanos, a leitura se desenvolverá, contudo, apenas sobre as perspectivas narrativas e na representação da personagem nos dois poemas, sem investir sobre aspectos da alusão formal no nível expressivo/poético, e trabalhando essas perspectivas em nível interdiscursivo.
\end{abstract}

PALAVRAS-CHAVE: Apolônio de Rodes; Ovídio; Medeia; arte allusiva.
* Doutorado em Estudos Literários pela Faculdade de Ciências e Letras de Araraquara, Universidade Estadual Paulista "Julio de Mesquita Filho" (UNESP).

\begin{abstract}
This text aims to analyse the influence of the remarkable appearance of the character Medea in Apollonius Rhodius' Hellenistic epic poem Argonautica - especially in the Book III - regarding its influence on the representation of the same character in the Book VII of Ovid's Metamorphosis. The analysis will take place mainly from the perspective of what is called arte allusiva, a procedure analogous to modern intertextuality, which focuses on the relations of influence between classical works. Starting from the influential relationship Hellenistic established with Roman writers, the perusal, however, will be developed only over the narrative perspectives as well as the character representation in the two poems, without dwelling on formal aspects of allusion at the expressive/ poetic level, and working with these perspectives at interdiscursive level.
\end{abstract}

KEYWORDS: Apollonius Rhodius; Ovid; Medea; arte allusiva. 


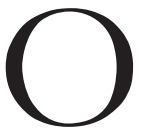

poeta romano Públio Ovídio Naso reúne, em seu grande poema Metamorfoses, um vasto catálogo de mitos diversos que, no entanto, desenham um conjunto coeso pela repetição da mesma unidade temática, justamente o processo de metamorfose que nomeia a obra. O poema é composto por 250 histórias em 15 livros e, apesar de iniciar seu extenso passeio pela mitologia pelo início dos tempos, não há nessa obra do poeta latino uma preocupação com a ordem especificamente cronológica dos acontecimentos, mas sim com uma distribuição coerente e coesa dos vários mitos de transfiguração que povoam o imaginário literário da Antiguidade Clássica até os dias atuais. Nesse sentido, o formato do poema foge da estrutura meramente catalógica, ganhando contornos de um poema cosmogônico, aos moldes da Teogonia, de Hesíodo.

Curtius faz observações sobre a importância e a influência das Metamorfoses de Ovídio, especialmente na Idade Média (1957, p. 50-51):

No início de As Metamorfoses o século XII encontrou uma cosmogonia e cosmologia acordes com o platonismo contemporâneo [...]. Mas as Metamorfoses eram também o repertório empolgante e romanesco da mitologia. Quem era Faetonte? Licáon? Procne? Aracne? Ovídio era o Who's Who para milhares de perguntas semelhantes. Era preciso conhecer as Metamorfoses muito bem; do contrário, impossível compreender os poetas latinos. Ademais, todas essas histórias mitológicas possuíam cunho alegórico. Ovídio também era, portanto, um repositório de moral. Dante ornamenta episódios do Inferno com metamorfoses que deviam sobrepujar Ovídio [...].

Para a construção de uma obra de tamanha magnitude, Ovídio empenhou todos os conhecimentos disponíveis da tradição literária anterior a ele, podendo ser recolhidas de seu poema várias fontes gregas e romanas. A metamorfose de seres mitológicos está presente na literatura desde a Ilíada, e a identificação das fontes de Ovídio é algo importante, já que diversos mitos que são amplamente conhecidos pelas artes, literatura, filosofia, etc. chegaram até nós principalmente por intermédio das Metamorfoses.

Dentre essas diversas fontes, destacam-se os poetas do chamado Período Helenístico, momento particular da literatura grega no qual houve uma produção artística muito diversificada em relação ao período Clássico, no que tange tanto aos temas abordados quanto à preocupação com o trabalho das formas literárias. A preocupação dos eruditos daquele momento, principalmente daqueles que frequentaram a famosa Biblioteca de Alexandria, era com o passado estabelecido da cultura de língua grega, que era por eles reavaliado e, portanto, a postura desses poetas passava a ser também a de críticos literários e, muitas vezes, de criadores de novas teorias estéticas.

No contexto dos chamados philólogoi, a postura em relação à produção poética mudou substancialmente, não apenas como reflexo de uma mudança da estrutura social, que deixava de ser a pólis do século $\mathrm{V}$ para um grupo de reinos derivados das conquistas de Alexandre Magno, mas a principal produção poética deixou de ser focada na poesia oral, na performance voltada para o público, e passou a ser essencialmente uma literatura privada, voltada para 
o indivíduo (Houghton, 1987, p. 34). É dessa literatura que bebem os poetas romanos, em um diálogo muito frutífero e constante.

Metamorfoses é um dos exemplares dessa influência, pois, como destaca O'Hara (2007, p. 118), o poeta "frequentemente se dedica à extensiva adaptação simultânea de fontes variadas"; na construção do longo poema hexamétrico. Além disso, para O’Hara, "seus empréstimos são caracterizados pela abrangência, o uso de variantes mitológicas, e a mistura e justaposição de material de diferentes gêneros". A discussão acerca do gênero em que se encaixam as Metamorfoses é extensa e em parte ainda muito complexa, pois mesmo sendo composta sob a forma de um extenso épico, em versos hexamétricos, é um poema cujo principal conteúdo são diversas histórias míticas reunidas sob o tema da metamorfose, sem um protagonista único a ser considerado o seu herói épico e sem um recorte mítico específico. Muitos dos episódios retratados no poema, como o próprio lamento de Medeia, tem uma natureza muito mais lírica que épica, por exemplo. Essa mistura de elementos formais de gêneros diversos é algo que não se restringe ao poema em questão, pois tanto nas Heroides quanto nas Pônticas, Ovídio utiliza-se do dístico, metro tradicional da elegia, mas compõe na forma de epístola. No caso das Metamorfoses, a obra se assemelha mais aos poemas de Hesíodo, Teogonia e Trabalhos e Dias, especialmente ao primeiro, catálogo de mitos e genealogias que também parte da origem dos tempos. Ainda assim é complexo avaliá-lo, como observa Zélia de Almeida Cardoso (2003, p. 83):

Não é uma epopeia, apesar do tom épico, dos versos hexâmetros e do emprego sistemático da narração. Não se caracteriza também como poema didático, pois que, mesmo que quiséssemos considerá-lo como uma tentativa de explicar o universo pela teoria neopitagórica que admite a reencarnação da alma, iríamos esbarrar, sem dúvida, na falta de qualquer fundamentação científica, no superficialismo e no tratamento irônico e brincalhão dado a algumas lendas.

A natureza variada do poema de Ovídio é atestada em todos os episódios narrados. Apesar da afirmação de muitos autores de que Metamorfoses se trata de um poema épico, Gonçalves aponta para a estrutura do poema, "que consiste de uma teia de mitos entrelaçados em uma cadeia narrativa, muito pouco lembra a épica heroica de Virgílio ou de Homero" (2011, p. 111). De fato, como observamos anteriormente, se não há um emprego sistemático da narração, como afirma Cardoso, há de certo modo um fio condutor que o assemelha aos moldes da poesia épica de raiz mitológica e cosmogônica, como os poemas de Hesíodo. Esse fio condutor se dá pelo procedimento da metamorfose, o que dá certo dinamismo à escritura do poema. A estratégia de Ovídio rompe a linearidade narrativa e busca, de certo modo, uma recolha de fragmentos da memória mítica, como aponta Carvalho (2010, p.11):

Nas Metamorfoses, Ovídio criou um modelo dinâmico de escritura, um tecido musical ininterrupto, capaz de abrigar em si um vasto imaginário, submetendo-o ao princípio único e constante de mutação de todas as coisas, num processo de repetição semelhante à técnica do leitmotiv na música, com seus temas e variações. As histórias 
sucedem umas às outras numa temporalidade que parte do instante da narração para qualquer outro ponto do passado ou mesmo do futuro, numa linha que recobre muito mais o in illo tempore da fábula do que os fatos considerados históricos. No entanto, as circunstâncias históricas determinam toda a narrativa, fazendo com que os personagens míticos ajam e sintam como seres humanos submetidos à sua lógica; além do mais, muitas das metamorfoses descritas são narrativas etiológicas que apontam para um estado de coisa atual. Ovídio opera contrapontisticamente dando ao passado atributos do presente. O poema é ao mesmo tempo uma recolha de contos e um diálogo dinâmico com a tradição literária e filosófica, através do jogo intertextual e alusivo. Ovídio condensa, amolda e reorganiza os dados da tradição e do contexto, traduzindo-os em novos termos, segundo o padrão de sua linguagem, tal como acontece a um mito, que é sempre a tradução em novos termos de um outro mito.

O fundamento, de tal modo, da construção do poema ovidiano é a dinâmica intertextual e alusiva que permite a recuperação constante de momentos distintos do mito registrados pela tradição, a partir de referências presentes. Se, como o famoso poema de Fernando Pessoa aponta, "o mito é o nada que é tudo", a recuperação que a alusão textual permite torna as Metamorfoses em si um texto sustentado sob um modo de pensar mítico, pelo qual não se aceita uma perspectiva temporal linear, mas cíclica, que reincide em si mesma em busca de seu sentido. O motor do poema é o tempo mítico, portanto, e de tal modo, justifica-se sua estrutura.

Ademais de o elo entre as narrativas estabelecer-se pelo processo de metamorfose, Rosner-Siegel (1982, p. 233-34) exemplifica essa variedade tomando como exemplo o tratamento de Medeia pelo poema:

A narrativa de Ovídio sobre as aventuras e desventuras de Medeia exemplifica a natureza variada das Metamorfoses. Ao mesmo tempo, ilustra a habilidosa mistura de Ovídio de temas do amor impróprio e proibido, e da metamorfose e deterioração psicológica da personagem principal no episódio como um resultado do amor e de outras fortes emoções. Ao apresentar a transformação de Medeia, Ovídio bebe de seu tradicional retrato como uma feiticeira, e simboliza sua mudança por seu progressivamente maior interesse e busca pelo mágico e o mal.

Não obstante, a participação de Medeia no poema de Ovídio não ocorre exclusivamente por um procedimento narrativo: a sua primeira aparição no Livro VII da obra acontece logo após um breve relato sobre a viagem e chegada dos argonautas à Cólquida, terra da jovem, onde se encontrava o Velocino Dourado. Então segue um extenso discurso introspectivo (v. 11-71), em primeira pessoa, totalmente permeado por situações de conflito emocional e calcado em diversas oposições, que configuram de maneira clara as angústias da jovem pelo conflito ocasionado por sua vontade - interferência direta do deus do amor 
personificado - de ajudar o jovem estrangeiro Jasão com sua magia e trair sua pátria. Esse monólogo interior também se faz presente na Argonáutica de Apolônio de Rodes e o próprio Ovídio já o havia apresentado na referida epístola XII das Heroides. E é difícil não considerar que, dada a já referida influência, haja aqui um procedimento alusivo do poeta romano com a obra do helenístico. Jolivet (2001, p. 194) observa como a arte alusiva, especialmente em Ovídio e nos poetas de seu tempo, é, justamente, herança dos poetas helenísticos:

A poesia latina herdou essas práticas da poesia helenística que repousam sobre uma íntima comunhão entre o autor e seu público. A mesma difusão da obra sobre o quadro de recitationes, em uma perspectiva de imitatio e de aemulatio, vem favorecer essa cumplicidade poética tão necessária ao exercício sutil da arte alusiva. Esses aspectos são fundamentais para a época augustana.

Os romanos chamavam a filiação de seus textos a outro modelo de imitatio, um recurso que não se restringia à retomada de modelos gregos, mas também latinos. Da mesma maneira, o objetivo da maioria desses escritores era a aemulatio, ir além da mera citação, buscando igualar em valor ou ainda superar o original, procedimento, portanto, abarcado pela imitatio (Vasconcellos, 2001, p. 18). Já a chamada arte allusiva é um termo consagrado por um artigo de 1942 de Giorgio Pasquali, no sentido próximo àquele da moderna intertextualidade. Porém, Vasconcellos (2007, p. 250-51) alerta para a essencial diferenciação dos termos:

Um outro ponto que queremos aflorar aqui é a questão da nomenclatura e da restrição do objeto de estudo. Embora estejamos conscientes de que o fenômeno da intertextualidade, se o tomarmos, como tantas vezes se faz, no sentido amplo de interdiscursividade, está presente em todo texto e em todo discurso, achamos conveniente recortar nesse fenômeno o caso da "arte alusiva" dos poetas antigos, uma espécie de arte compositiva da qual fazia parte a citação mais ou menos indireta dos predecessores. Uma proposta de recorte teórico seria distinguir no campo geral da interdiscursividade, o fenômeno da intertextualidade, restringindo o emprego desse termo à incorporação de um ou mais textos por outro. E, no campo da intertextualidade, focalizaríamos a atenção, como estudiosos de literatura latina, no que Pasquali chamava "arte alusiva", compreendendo-a como uma espécie de técnica compositiva de evocação mais ou menos explícita de outros textos de maneira a criar significados a serem interpretados pelo leitor. Essa arte alusiva é sutil e complexa, e um poeta como Virgílio evoca, em sua epopeia, toda a tradição poética grega e latina para com ela dialogar das mais variadas formas.

Aliás, é importante salientar que a chamada arte alusiva é um procedimento justamente helenístico, ao que os romanos como Ovídio também assimilam na sua produção. Todo o trabalho realizado na Biblioteca de Alexandria tinha em vista, como já se observou, a revisão e a reflexão sobre a tradição literária grega. Biblioteca, aliás, que era presidida por 
um bibliotecário-chefe que, segundo as fontes disponíveis, também assumia a tutoria dos filhos do monarca (Rodrigues Jr., 2005, p. 16). Como se sabe, um destes bibliotecários foi o próprio Apolônio de Rodes.

Há três aspectos fundamentais da personagem Medeia que convergem na sua representação dentro da literatura grega: o feminino, o estrangeiro e o feiticeiro. Como mulher, encontramos no mito dois momentos: o da jovem insegura, que sofre pelo seu amor proibido pelo jovem e belo estrangeiro Jasão, e o da mulher mais velha que, ao ver-se abandonada e ferida em sua timé, torna-se forte e exige o cumprimento das promessas feitas a ela quando jovem, mediante uma terrível vingança. O dilema surge pelo segundo aspecto, o da estrangeira, que decide abdicar de sua família e país em prol de seu amor, mas que traz a marca de ser uma estrangeira, desonra diante de seu povo. Como feiticeira, ela é sempre representada dentro do universo das artes obscuras, que envolvem aspectos relacionados à deusa Hécate e a sua linhagem como neta de Hélio - daí a sua relação com a feiticeira Circe, sua tia.

Podem-se reduzir esses três aspectos a duas representações de Medeia, que serão seu retrato mais comum: a insegura jovem estrangeira feiticeira que vive em um conflito entre seus deveres junto à família e à pátria e a forte mulher estrangeira feiticeira, que se sente preterida pelo marido e desonrada perante os juramentos feitos por ele.

Apesar de seu poema épico ser posterior à famosa tragédia de Eurípides, Apolônio narra eventos anteriores aos da Medeia, ou seja, retrata justamente a primeira Medeia. Mas, mesmo quando a jovem (III, v. 985-98) exige de Jasão que mantenha a sua palavra, de que a levaria para o seu reino - palavras essas deixadas de lado quando ele decide abandonála para livrar-se da perseguição dos colcos -, e convence-o do assassinato, Apolônio faz uma óbvia alusão a Eurípides, tanto para construir Jasão quanto em sua representação de Medeia. É evidente que, mesmo estando situada em diferentes momentos da representação da personagem, a Medeia de Apolônio possui elementos da Medeia de Eurípides - pois é impossível, após a leitura feita pelo tragediógrafo, ignorar certos traços da personagem.

Além disso, a referida cena do canto terceiro reitera que, para Jasão, o objetivo único de sua viagem é sempre o mesmo: retornar com o velo para retirar Pélias do trono. Não há amor por parte de Jasão, apenas o desejo de cumprir seu objetivo, sendo Medeia o útil instrumento para tanto. Uma possível interpretação das ações do herói a partir do amor que ele possuiria pela jovem seria errônea, pois ele não demonstra nutrir qualquer amor verdadeiro por ela. De tal modo, ele apenas estava cumprindo com a palavra dada, de levá-la embora para a sua terra. Não apenas as atitudes de Jasão e Medeia transparecem a leitura de Eurípides, como toda a obra de Apolônio é permeada por elementos que dialogam com a tragédia ${ }^{1}$.

A Medeia de Ovídio também ecoa a de Eurípides, como observa Pavlock (2009, p. 43):

Estudiosos têm há muito reconhecido a dívida com a Medeia de Eurípides no reconhecimento da jovem mulher da dificuldade de encerrar sua paixão pelo estrangeiro. A medida que ela encara seu

\footnotetext{
${ }^{1}$ Cf. Diniz, 2012.
} 
dilema, ela se sente puxada em direções opostas: "sed trahit invitam nova vis, aliudque cupido,/ mens aliud suadet" ("Mas uma força estranha me arrasta contra minha vontade, e o desejo incita uma coisa, a razão outra"[19-20]). Ela então resume seu predicamento: "video meliora proboque, / deteriora sequor?" ("Eu vejo e aprovo o melhor curso, mas eu persigo o pior!" [20-21]). Com essa introspecção moral, Medeia ecoa sua contraparte euripidiana, que assevera que, apesar de ela entender o caminho maligno no qual ela embarca, sua raiva é mais forte que sua razão (1078-79).

O monólogo de Medeia em Ovídio traz, de tal modo, o mesmo efeito alusivo encontrado em Apolônio. Ovídio, como aponta Sánchez (1996, p. 279, n. 633) claramente imita Apolônio em Met. VIII, v. 108ss, porém na voz de Cila, ao interpelar o rei Minos - assim como Virgílio o imitara no diálogo de Dido e Eneias em En., IV v. 305ss. Não apenas, contudo, nessas palavras específicas, pois todo o conflito emocional de Medeia, que permeia o canto III da Argonántica, parece exercer grande influência para atitudes similares de personagens femininas da literatura latina.

Em III, v. 464-70, Medeia expressa seu conflito interno após ver o jovem²:

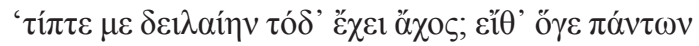

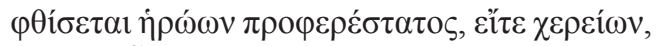

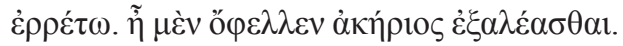

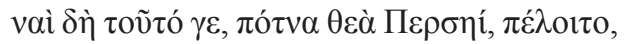

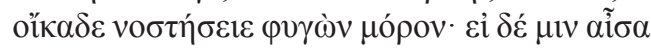

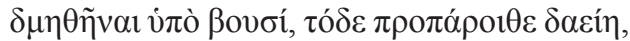

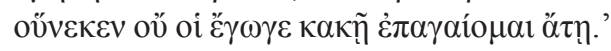

"Por que me toma, desgraçada, essa dor?

Ele perecerá, seja o mais excelente dos heróis ou o pior, que pereça! Em verdade, quem dera livre-se ileso! Sim, que ao menos isso, augusta deusa Perseida, aconteça, que retorne para casa evitando a fatalidade. Se porém seu destino é ser sobrepujado pelos touros, saiba antes isso, que eu não me alegro com sua funesta perdição".

\footnotetext{
${ }^{2}$ Todas as passagens da Argonáutica foram traduzidas e analisadas a partir da edição estabelecida e comentada por Mooney (1912). Para facilitar o acesso às análises de termos específicos, todas as palavras gregas discutidas no texto estão transliteradas em caracteres latinos, com os sinais diacríticos correspondentes, de acordo com as "Normas para a transliteração de termos em grego antigo", da Revista Classica, disponíveis em: http://classica.org.br/cla/v19/Classica\%20Brasil\%2019.2\%20 298-299\%202006.pdf. Versos completos e passagens mais longas não sofreram transliteração. Em alguns casos, transcreveu-se o termo grego referido junto à palavra escrita em caracteres gregos, mas apenas em suas primeiras aparições; nas seguintes, manteve-se apenas a transcrição, exceto quando a identificação da palavra grega citada no texto for importante para o contexto da análise.
} 
É possível notar o conflito emocional mediante a utilização de figuras como antíteses e litotes, a afirmação pelo contrário (Sánchez, 1996, p. 225, n. 448), que são base, junto a diversos oximoros, de todo o monólogo das Metamorfoses. O centro desse monólogo é esse conflito, que transparece em Apolônio não apenas pelas palavras e pensamentos de Medeia, mas pelo próprio comportamento da jovem, que realiza movimentos permeados de indecisão e angústia, numa repetição que desenha uma angustiada coreografia de idas e vindas, em III, v. 645-55. A seguir, o sofrimento de Medeia é comparado ao angustiante pesar de uma jovem noiva que perde o futuro marido e então, novamente, lamenta sua condição, em III, v. 674-80.

Já em Ovídio, toda a sequência do monólogo é permeada pela angústia do conflito entre amor e dever. Essa sequência, como destaca Pavlock (2009, p. 41), traz não apenas uma tensão emocional, mas uma surpreendente habilidade retórica. Para a autora, em VII, v. 23-24, Medeia "espertamente emprega uma anáfora ao repetir o subjuntivo niuat, mas mudando sua função gramatical de uma questão indireta para um comando exortatório”: [...] uinat, an ille/ occidat, in dis est; uiuat tamen!/ "Que ele viva ou morra depende dos deuses.

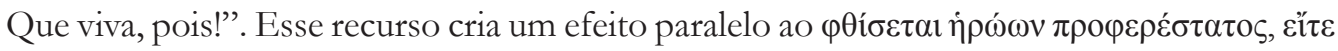

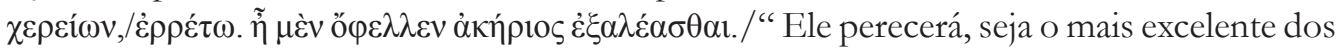
heróis/ou o pior, que pereça! Em verdade, quem dera/livre-se ileso!”. No caso do grego, a construção é similar, com dois verbos diferentes mas que, no contexto, significam ambos "perecer". O primeiro verbo é conjugado no futuro, $\varphi \theta i ́ \sigma \varepsilon \tau \alpha \imath$ (phthisetai), indicando a certeza de um futuro funesto, e o segundo no imperativo, é $\rho \rho \varepsilon ́ \tau \omega$ (errétô), uma exortação idêntica a uiuat tamen! O efeito das frases é similar, mas Ovídio prefere que sua Medeia deseje a vida do herói, não a morte, sob a vontade dos deuses. Fica evidente, pelo paralelo, que Ovídio constrói sua sentença tendo em vista a construção de Apolônio ${ }^{3}$.

Outro ponto crucial da representação de Medeia em Apolônio, no que tange sua influência, é o monólogo da jovem em III, v. 772-801. Scholes \& Kellogg (1977, p. 127) destacam as singularidades desse monólogo:

[...] Medeia, atingida pela flecha, vê-se dividida entre sua paixão recente e sua lealdade para com seu pai. Ela não tem a quem confiar todos os seus pensamentos. Procura resolver seu dilema num debate consigo mesma. Apolônio trata sua luta interior detalhadamente, combinando a análise narrativa com um longo trecho de monólogo interior. Podemos separar as características da passagem numa série de itens a serem comparados com outros usos desta técnica: 1) o monologuista é mulher (todos de Homero eram homens); 2) ela está

\footnotetext{
${ }^{3}$ Não obstante, o último verso do poema traz o mesmo verbo, numa exortação do eu poético de Ovídio, que deseja que ele viva pelos seus versos - Siquid habent ueri uatum praesagia, uinam. Não há como não traçar um paralelo com o encerramento da Argonántica, na qual Apolônio também exorta a

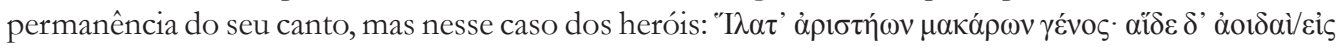

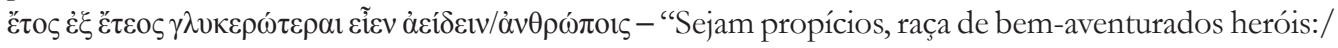
Que estes cantos ano após ano sejam mais doces de cantar/entre os homens” (Arg. IV, v. 1773-75).
} 
apaixonada; 3) o momento é de crise; 4) ela vê-se dividida entre o que é "certo" e o que é impelida a fazer, neste caso, entre lealdade e paixão; 5) sua situação é tal que não pode confiar em ninguém; 6) ela encara o suicídio como uma possibilidade.

Além de servir como referência direta para o monólogo inicial do livro VII das Metamorfoses, como observam Scholes \& Kellogg, esse monólogo é recuperado por Ovídio em toda obra (Scholes \& Kellogg, 1977, p. 128), como um referencial para o monólogo feminino que, aliás, como os autores salientam, é um procedimento inexistente em Homero.

Pavlock destaca essa relação, ainda, quando, no monólogo ovidiano, Medeia se questiona sobre a fidelidade de Jasão (2009, p. 46)

Et dabit ante fidem, cogamque in foedera testes esse deos. Quid tuta times? accingere et omnem pelle moram: tibi se semper debebit Iason, te face sollemni iunget sibi, perque Pelasgas servatrix urbes matrum celebrabere turba.

'Dará a palavra antes e invocarei os deuses como testemunhas do nosso pacto. Que temes tu, estando segura? Apronta-te, sem mais demoras. Jasão terá uma dívida eterna para contigo, contigo casará em solene boda, e pelas cidades dos Pelasgos serás aclamada por multidões de mães como sua salvadora.'

Aqui Ovídio estabelece um diálogo com a passagem do canto III na qual Jasão interpela Medeia pedindo seu auxílio. Essa estratégia retórica utiliza-se da proposição de um pagamento à ajuda de Medeia: a glória. Pavlock observa que "o herói, sentindo a agitação da jovem, tranquiliza-a ao afirmar que ele e seus companheiros irão espalhar sua fama na Grécia e que suas mulheres e mães farão o mesmo (v. 990-95):

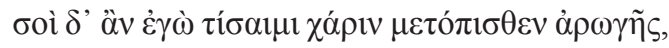

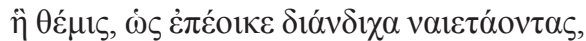

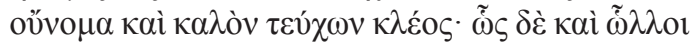

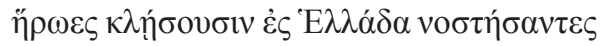

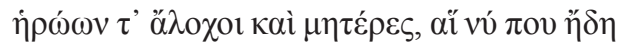

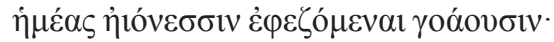

\footnotetext{
${ }^{4}$ As citações das Metamorfoses serão realizadas a partir do texto traduzido por Farmhouse, de 2007, com o texto latino retirado da edição de Hugo Magnus, de 1892, disponível na base de dados Perseus. Como no caso da edição da Argonautica de Mooney, o acesso a essa edição facilitou o processo de apresentação por já ser um texto digitalizado no formato unicode.
} 
A ti eu poderia pagar depois o favor da ajuda,

como é devido, como cabe aos que habitam terras distantes, produzindo renome e bela glória. Assim os outros

heróis louvar-te-ão ao regressar para Hélade e as esposas e mães dos heróis, as quais agora em algum lugar já nos choram sentadas junto às praias.

E, para convencer a jovem de suas intenções, Jasão utiliza-se de um exemplo, sugerindo a Medeia o seu destino (v. 990-1007):

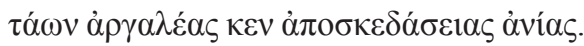

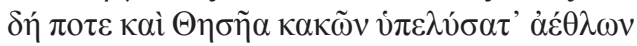

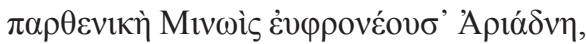

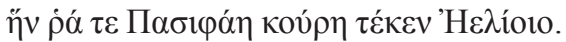

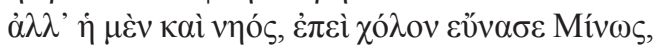

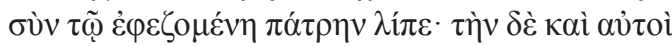

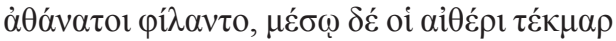

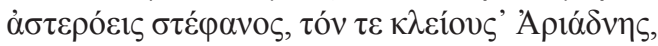

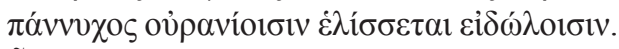

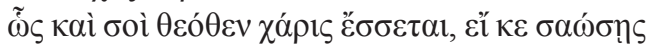

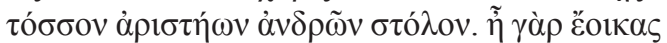

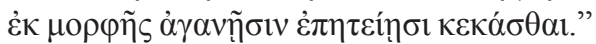

As dolorosas tristezas dessas tu poderias dispersar.

Uma vez também a Teseu libertou de maléficas provas

a jovem filha de Minos, bondosa Ariadne, a qual dera a luz Pasífae, filha de Hélio.

Mas a bordo de uma nau, após acalmada a ira de Minos, 1000 Com aquele a pátria abandonou; a ela também os próprios imortais amaram, e no meio do céu, como sinal uma coroa estrelada, chamada Ariadne, toda noite gira entre as constelações celestiais. Assim tu graças dos deuses terás, se salvares 1005 tal expedição de homens valorosos. Em verdade pois pareces pela beleza distinguir-se em gentil bondade.

O discurso de Jasão coloca Medeia como aquela a quem os próprios deuses louvarão como salvadora ( $\sigma \alpha \omega ́ \sigma \emptyset n s /$ saôsèis) da expedição, assim como a Medeia de Ovídio, que afirma que será aclamada pelas mães por ser a salvadora (seruatrix $)^{5}$. Mas, de forma irônica, a retórica de Jasão que serve ao seu propósito, recuperar o velocino, também o levará inconscientemente ao pacto de amor e honra que culminará em toda a tragédia conhecida. Ao citar a morte como única capaz de separá-los, Jasão apenas está ratificando a principal diferença entre Ariadne e Medeia: a última se vingará do futuro abandono de seu amado.

\footnotetext{
${ }^{5}$ Referência que também recupera a relação entre Medeia e Ártemis, que no verso 570 do canto I da

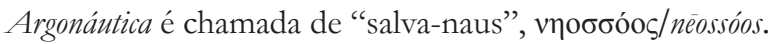


Ao comparar a jovem com Ariadne, Apolônio faz ainda seu herói lembrar-se não apenas do mito citado, mas do futuro daquele casal, como observa Goldhill (1991, p. 303):

Isso leva a um segundo ponto. Por mais que Apolônio nos leve de volta a um tempo anterior às narrativas de Homero, sua Medeia é, claramente, uma jovem representação de uma das mais famosas figuras do cenário trágico do século quinto. Muitos críticos têm esboçado maneiras nas quais a imagem da Medeia de Apolônio é interpretada frente à grande e violenta bruxa da peça de Eurípides. $\mathrm{O}$ futuro de Medeia é um importante pano de fundo aqui. O "renome e bela glória” que ela terá na Grécia será por meio de um infanticídio e o ódio violento do marido enganador, que tenta a trocar por uma noiva nova. O humor dessa passagem pode jazer na sedução retórica de Jasão de uma inocente Medeia. Mas Jasão é também o ludibriado, enquanto sua linguagem involuntariamente o revela como a futura vítima de uma tentativa de tratar Medeia como Ariadne. Jasão está atraindo para si o caminho rumo à tragédia.

Ao insistir que Medeia será venerada na Hélade, Jasão faz uma promessa de fidelidade que tem um desenrolar claramente irônico, haja vista a clara referência à "inevitável morte" como a única capaz de separá-los (III, v. 1120-130):

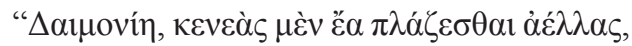

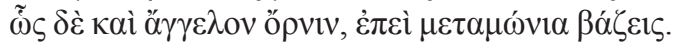

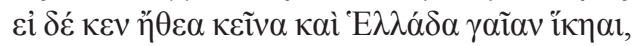

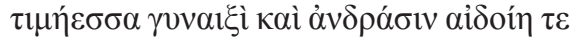

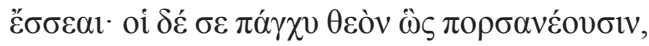

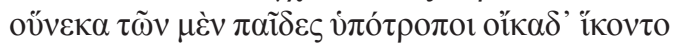

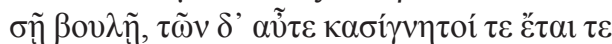

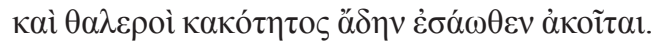

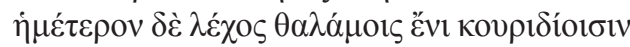

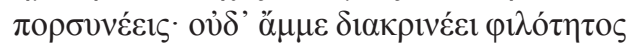

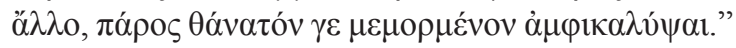

Desgraçada, deixe as vãs tempestades vagarem, assim como um pássaro mensageiro, pois falas em vão.

Se àqueles lugares e à terra da Hélade chegas Por mulheres e homens reverenciada e estimada serás; eles a ti completamente como uma deusa honrarão, porque os filhos de uns retornaram para casa por teu desígnio, e de outros, ainda, irmãos e parentes e também os robustos maridos da total ruína se salvaram.

Nosso leito prepararás em legítimo tálamo; nada nos separará de nosso amor até que a inevitável morte nos envolva. 
Goldhill atenta para a ironia da situação que segue: quando Medeia explica a Jasão seus rituais, pede para que ele não se esqueça do nome dela (III, v. 1069-70) e pergunta sobre as origens de Jasão e sobre Ariadne, que não conhece - embora ela seja sua parenta, já que Pasífae, mãe de Ariadne, é irmã de Eetes (III, v. 1071-76). Jasão descreve a sua genealogia e a localização de Iolco, mas interrompe o discurso e indaga do porquê de Medeia querer saber tais informações sobre ele e Ariadne. Goldhill destaca, ainda, que Jasão recusa-se a falar mais sobre a jovem, apenas repetindo seu nome e glória, e isso pode servir ironicamente

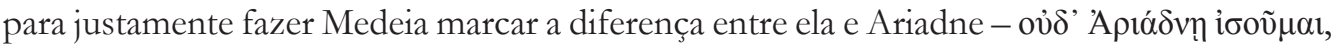
III, v. 1107 -, ao mesmo tempo que relembra, mais uma vez, que essa história culminará na tragédia de Eurípides.

Ovídio, de tal modo, recupera o tema do esquecimento no verso 50, ut timeam fraudem meritique oblivia nostri/ "não receio traição ou esquecimento dos meus serviços", e a seguir constrói um paralelo ainda mais evidente com a cena da Argonántica: ao afirmar no verso 60 que "quo coninge felix/ et dis cara ferar et vertice sidera tangam/ "E, tendo-o como esposo, serei chamada/ venturosa e cara aos deuses, e com a cabeça tocarei os astros", Medeia recupera imagem da coroa de Ariadne, também este um presente dos deuses para a jovem (III, v. 1001-4).

Todos esses exemplos evidenciam não apenas a influência do texto de Apolônio - e de Eurípides - sobre o de Ovídio, mas demonstram como ele busca evidenciar a alusão a suas fontes a partir de suas escolhas narrativas e poéticas. Mesmo que possamos recuperar todas as características do conflito emocional da jovem no poema helenístico, a habilidade do poeta romano em reconstruir as nuances de suas influências constitui uma perspectiva singular sobre a personagem Medeia, que, como se espera de uma arte allusiva, bebe da tradição sem perder a sua originalidade poética.

\section{REFERÊNCIAS}

APOLLONIUS RHODIUS. The Argonautica. Edited with introd. and commentary by George W. Mooney. London: Longmans, Green and Co., 1912.

APOLONIO DE RODAS. Argonáuticas. Trad. de Mariano Valverde Sánchez. Madrid: Editorial Gredos, 1996.

APOLONIO DE RODAS. Las Argonáuticas. Trad. de Máximo Brioso Sánchez. Madrid: Ediciones Cátedra, 2003.

CARDOSO, Z. de A. A literatura latina. São Paulo: Martins Fontes, 2003.

CARVALHO, R. N. B. de. Metamorfoses em tradução. Relatório Final apresentado ao Programa de Pós-graduação em Letras Clássicas. São Paulo: Departamento de Letras Clássicas e Vernáculas da Faculdade de Filosofia, Letras e Ciências Humanas da Universidade de São Paulo, 2010. Disponível em: <http://www.usp.br/verve/coordenadores/raimundocarvalho/ rascunhos/metamorfosesovidio-raimundocarvalho.pdf>. Último acesso: 10 de janeiro de 2016. 
CURTIUS, E. R. Literatura Européia e Idade Média Latina. Rio de Janeiro: Instituto Nacional do Livro, 1957.

DINIZ, F. G. M. Do dramático ao épico: a presença da tragédia na Argonáutica de Apolônio de Rodes. Itinerários - Revista de Literatura, v. 34, p. 71-80, 2012.

EURIPIDES. Euripides in four volumes. With an English Translation by Arthur Way. Cambridge: Harvard University Press, 1939.

GOLDHILL, S. The poet's voice: Essays on poetic and greek Literature. Cambridge: Cambridge University Press, 1991.

GONÇALVES, R. T. (org.). Uma tradução coletiva das Metamorfoses 10.1-297 com versos hexamétricos de Carlos Alberto Nunes. Scientia Traductionis, v. 10 (Textos Clássicos e Tradução), p. 110-132, 2011. Disponível em: <https://periodicos.ufsc.br/index.php/scientia/ article/viewFile/1980-4237.2011n10p110/20033>. Último acesso: 10 jan. 2016.

HOUGHTON, V. L. Apollonius Rhodius' Argonautica: the feminine principle. Michigan: UMI, 1987.

JOLIVET, Jean-Christophe. Allusion et Fiction Épistolaire dans les Héroïdes: recherches sur l'intertextualité ovidienne. Rome: École Française de Rome, 2001.

O'HARA, J. J. Inconsistency in Roman Epic: Studies in Catullus, Lucretius, Vergil, Ovid and Lucan. Cambridge: Cambridge University Press, 2007.

OVID. Metamorphoses. Hugo Magnus (ed.). Gotha: Friedr. Andr. Perthes, 1892. Disponível em: <http://www.perseus.tufts.edu/hopper/text?doc=Perseus\%3atext\%3a1999.02.0029>. Último Acesso: 19 out. 2013.

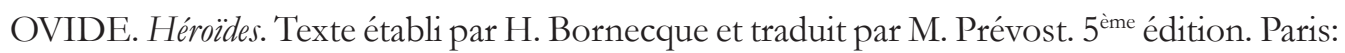
Les Belles Lettres, 2005.

OVÍDIO. Metamorfoses. Trad. de Paulo Farmhouse. Lisboa: Cotovia, 2007.

PAVLOCK, Barbara. The image of the poet in Ovid's Metamorphoses. Madison: University of Wisconsin Press, 2009.

RODRIGUES JR. F. Canto III da Argonáutica de Apolônio de Rodes. Dissertação de Mestrado. São Paulo: Programa de Pós-Graduação em Letras Clássicas da Faculdade de Filosofia, Letras e Ciências Humanas da Universidade de São Paulo, 2005.

ROSNER-SIEGEL, J. Amor, Metamorphosis and Magic: Ovid's Medea (Met. 7.1-424). Classical Journal, v. 77, n. 3, p. 231-243, 1982. Disponível em: <http://www.jstor.org/stable/3296973>. Último acesso: 30 jul. 2013.

SCHOLES \& KELLOGG. A naturez̧a da narrativa. Tradução de Gert Meyer. São Paulo: McGraw-Hilll, 1977. 
VASCONCELLOS, P. S. de. Efeitos intertextuais na Eneida de Virgílio. São Paulo: Humanitas, 2001.

VASCONCELLOS, P. S. de. Reflexões sobre a noção de "arte alusiva" e de intertextualidade no estudo da poesia latina. Classica (Brasil), v. 20, n. 2, p. 239-260, 2007. Disponível em: $<$ http://classica.org.br/revista/pdf/20/2/ClassicaBrasil_20.2_239-260.pdf>. Último Acesso: 16 out. 2013.

Recebido em: 13 de setembro de 2014 Aprovado em: 1 de março de 2016 